\title{
Growth and nutrient uptake by Schoenoplectus californicus (C.A. Méyer) Sójak in a constructed wetland fed with swine slurry
}

\author{
M.E. Neubauer, C. Plaza de los Reyes, G. Pozo, C.A. Villamar and G. Vidal* \\ Engineering \& Biotechnology Environmental Group, Environmental Science Center EULA - Chile, University \\ of Concepción. P.O. Box 160- C, Concepción-Chile. Tel.: +56-041-220 4067. Fax: +56-041-220 7076. \\ "Corresponding author: glvidal@udec.cl
}

\begin{abstract}
Schoenoplectus californicus (C.A. Meyer), Soják is one of the plants most used to treat wastewater in a constructed wetland. Our objective is to study the growth and nutrient uptake of Schoenoplectus californicus Cyperaceae in a constructed wetland fed with swine slurry. The methodology used to evaluate the growth of the Schoenoplectus californicus Cyperaceae was to evaluate the allometric, relative abundance and biomass of the plants in the period $2009-2010$.

The results show that Schoenoplectus californicus had allometric growth between 31.2 to 98.4 and relative abundance between 21 to 108 individuals $\mathrm{m}^{-2}$, during the fall and spring seasons, respectively. These results are influenced by the nitrogen content (between 0.05 to $2.0 \mathrm{~kg} \mathrm{~N} \mathrm{ha}^{-1} \mathrm{~d}^{-1}$ ) present in the constructed wetland. In this same period, the increase in Schoenoplectus californicus biomass ( $28 \%)$ is related to a decrease in nitrogen loading between 2.0 to $0.05 \mathrm{~kg} \mathrm{~N} \mathrm{ha}^{-1} \mathrm{~d}^{-1}$. Aboveground biomass was greater (500 to $724 \mathrm{~g} \mathrm{~m}^{-2}$ ) than belowground biomass ( 4.8 to $22.7 \mathrm{~g} \mathrm{~m}^{-2}$ ). Due to nutrient translocation in spring-summer, the N:P ratio aboveground ranged from 9 to 16, while belowground the ratio varied from 7 to 10 .
\end{abstract}

Keywords: Schoenoplectus californicus (C.A. Méyer) Sójak, constructed wetland, nutrients, swine slurry 


\section{Introduction}

In Chile, during the last twenty years, farming increases about $9 \%$ year $^{-1}$, generating about 1.7 million of animals year ${ }^{-1}$ and 44 mil ton of swine slurry year $^{-1}$ (FAO, 2010) characterized by high organic matter content $\left(>10.0 \mathrm{~g} \mathrm{DQO} \mathrm{L}^{-1},>3.0 \mathrm{~g} \mathrm{DBO}_{5} \mathrm{~L}^{-1}\right)$, nutrients $\left(>1.8 \mathrm{~g} \mathrm{~N}_{\mathrm{T}} \mathrm{L}^{-1},>1.4 \mathrm{~g} \mathrm{NH}_{4}^{+} \mathrm{L}^{-1},>0.5 \mathrm{~g} \mathrm{PO}_{4}^{-3}\right.$ $\left.\mathrm{L}^{-1}\right)$, salts $\left(>11.8 \mathrm{mS} \mathrm{cm}^{-1},>2.3 \mathrm{~g} \mathrm{Cl}^{-} \mathrm{L}^{-1}\right)$ and other compounds (Moral et al., 2008). Consequently, livestock farms need to reduce organic matter and nutrient content in swine slurry prior to use in irrigation. An alternative technology designed for reuse and nutrient recycling through interaction of plants, soil and bacteria (Brix, 1997) is the Surface Flow Wetland (SFW), inoculated with aquatic vascular plants. This technology achieves removal efficiencies between 18 to 80 $\%$ in phosphorus and between 16 to $95 \%$ in nitrogen (Hunt et al., 2001; Poach et al., 2003; Lee et al., 2009). Through their growth, vascular aquatic plants directly (by assimilation) and indirectly (through bacteria attached to rhizome, oxygen dosing, stabilisation of substrate, filtration, prevention of clogging and thermal isolation) influence the reduction of nutrient content (nitrogen and phosphorus) in constructed wetlands (Brix, 1994; Brix, 1997). The most commonly used genus of aquatic vascular plants are Typha spp., Schoenoplectus spp. and Phragmites spp. due to their wide tolerance to changes in the $\mathrm{pH}(4-10)$, salinity $\left(20-45 \mathrm{mg} \mathrm{Cl}^{-} \mathrm{L}^{-1}\right)$, temperature $\left(10-32{ }^{\circ} \mathrm{C}\right)$ and nutrient assimilation (200 - $550 \mathrm{~kg} \mathrm{~N}^{-1} \mathrm{year}^{-1}, 30$ - 150 kg P ha ${ }^{-1}$ year $^{-1}$ ) (Reddy and D'Angelo, 1997; Stein and Hook, 2005). Indeed, Typha latifolia tends to concentrate nitrogen in its apices $\left(22.9 \mathrm{mg} \mathrm{N} \mathrm{kg}^{-1}\right)$ and phosphorus in its roots $\left(6500 \mathrm{mg} \mathrm{P} \mathrm{kg}^{-1}\right)$. However, under similar conditions, Phragmites australis (2500 $\mathrm{kg} \mathrm{N} \mathrm{ha}^{-1}$ year $^{-1}, 200 \mathrm{~kg} \mathrm{P} \mathrm{ha}^{-1}$ year $\left.^{-1}\right)$ can absorb more nutrients than Typha latifolia (1300 $\mathrm{kg} \mathrm{N} \mathrm{ha}^{-1}$ year $^{-1}$, $200 \mathrm{~kg} \mathrm{P} \mathrm{ha}^{-1}$ year $^{-1}$ ) (Brix, 1994), and Schoenoplectus validus $\left(1-13 \mathrm{mmol} \mathrm{HPO}_{4}^{-} \mathrm{g}^{-1}\right.$ roots $)$ is able to assimilate more phosphorus than Canna indica (2-14 mmol $\mathrm{HPO}_{4}^{-} \mathrm{g}^{-1}$ roots) (Zhang et al., 2009). These results are related to nutrient availability, selectivity, toxicity and requirements of the plants. On the one hand, the nutrient availability is influenced by anoxic conditions $(<100 \mathrm{mV})$ in the wetland soil, favouring ammonium $\left(\mathrm{NH}_{4}^{+}\right)$over nitrate $\left(\mathrm{NO}_{3}^{-}\right)$and the phosphorus precipitation (Lissner et al., 2003). On the other hand, it has been observed that Typha latifolia prefers ammonium ( $>2000 \mathrm{mmol} \mathrm{NH}_{4}^{+} \mathrm{g}^{-1}$ ) since it achieves optimal growth at a slightly acid $\mathrm{pH}$ between 6.5 to 7 (Brix et al., 2002). However Canna indica prefers $\mathrm{NO}_{3}^{-}\left(10-140 \mathrm{mmol} \mathrm{NO}_{3}^{-} \mathrm{g}^{-1}\right.$ roots $)$, due to its low adaptability to anoxic conditions (Zhang et al., 2009), and also because the $\mathrm{NH}_{4}^{+}$, at concentrations above $100 \mathrm{mg} \mathrm{L}^{-1}$, can be toxic (Clarke and Baldwin, 2002). Finally, the plant nutrient requirements are also seasonal. Additionally, it has been observed that Typha latifolia needs more nutrients in the fall $\left(0.37-1.76 \mathrm{~kg} \mathrm{~m}^{-2}\right)$ than in the winter $(0.33-1.38 \mathrm{~kg} \mathrm{~m}$ -2) (Madisson et al., 2009).

The aquatic vascular plants of the Cyperaceae family in constructed wetland are used because they achieve the highest dosage of oxygen $(\sim 0.5$ to $3.1 \mathrm{mg}$ $\mathrm{O}_{2} \mathrm{~L}^{-1}$ ) (Gebremarian et al., 2008), favouring a seasonal aerobic microhabitat $(>200 \mathrm{mV}$ ) in the rhizome zone (Bezbaruah and Zhang, 2004) and the nitrification process (Vymazal et al., 2010). Schoenoplectus validus and Schoenoplectus pungens have been observed to produce more oxygen $\left(0.5-3.1 \mathrm{mg} \mathrm{O}_{2} \mathrm{~L}^{-1}\right)$ than $T y$ pha latifolia (1.2 - $\left.1.7 \mathrm{mg} \mathrm{O}_{2} \mathrm{~L}^{-1}\right)$ (Reddy et al., 1989), also preventing the toxicity caused by nitrification of ammonium. Indeed, Schoenoplectus tabernaemontani can be inhibited to concentrations greater than $100 \mathrm{mg}$ $\mathrm{NH}_{4}^{+} \mathrm{L}^{-1}$, while Typha latifolia is inhibited to concentrations greater than $200 \mathrm{mg} \mathrm{NH}_{4}^{+} \mathrm{L}^{-1}$ (Clarke and Bald- 
win, 2002). However, Schoenoplectus grossus has been observed to recover its growth since the number of individuals $\mathrm{m}^{-2}$ increases (from 38 to 175) during ammonium nitrification (Jinadasa et al., 2006), which is often seasonal. Carex rostata and Schoenoplectus acutus have been observed to suffer variations between an anoxic environment $(<-150 \mathrm{mV})$ at temperatures of 24 to $26^{\circ} \mathrm{C}$ (summer-spring) and an aerobic environment $\left(>200 \mathrm{mV}\right.$ ) at temperatures between 8 and $15^{\circ} \mathrm{C}$ (winter-fall) (Stein and Hook, 2005). The variations seasonal in the soil environment can influence the growth and nutrient uptake in Cyperaceae. Schoenoplectus validus can increase its biomass to $581 \mathrm{~g} \mathrm{~m}-2$ with the increase in nutrient availability (103 $\mathrm{mg} \mathrm{N} \mathrm{d}^{-1}, 17.1 \mathrm{mg} \mathrm{P} \mathrm{d}^{-1}$ ), where nitrogen (> $\left.296 \mathrm{mg} \mathrm{N} \mathrm{d}^{-1}\right)$ is more influential for its rhizome growth (Zhang et al, 2008).

For these reasons, the objective of the present study is to evaluate the growth and nutrient uptake of Cyperaceae Schoenoplectus californicus (C.A. Méyer) in constructed wetland fed with swine slurry.

\section{Materials and methods}

\subsection{Study area}

The study area was a swine fattening farm $(>8000$ swine) located in central Chile (36 $33^{\prime} 19.61^{\prime \prime} \mathrm{S}$; $71^{\circ} 51^{\prime} 49.64^{\prime \prime}$ W). During the period 2009 to 2010 , the average daily temperatures were in the range of 4.9 to $21.1^{\circ} \mathrm{C}$ in fall (March to June) and spring (September to December), in the range of 13.8 to $24.8^{\circ} \mathrm{C}$ in summer (December to March) and 2.2 to $15.1^{\circ} \mathrm{C}$ in winter (June to September). Rainfall was concentrated from May to August (101 to $276 \mathrm{~mm} \mathrm{month}^{-1}$ ), while evaporation was relevant between November to February (129 to $192 \mathrm{~mm} \mathrm{month}{ }^{-1}$ ). The constructed wetland (0.30 ha) is located in the fattening farm and is a Wetland Surface Flow (0.7 m depth), piston flow (10 chan- nels with 6 zones) and operated at the nitrogen rate loading between 0.05 to $0.20 \mathrm{~kg} \mathrm{~N}^{-1} \mathrm{~d}^{-1}$. Schoenoplectus californicus (C.A. Méyer) Sójak is distributed throughout the wetland. The frequency sampling was seasonal with 60 plants evaluated each period.

\subsection{Field sampling}

\section{Plant sampling}

Ten plants were randomly selected in 6 zones ( $\mathrm{S} 1$ to S6) identified throughout the wetland. The sampled plants were labelled and evaluated with allometric measurements: height (from the base to the apex), basal diameter and relative abundance (individuals $\mathrm{m}^{-2}$ ), with a PVC quadrant of $1 \mathrm{~m}^{2}$ (Perbangkhem and Polprasert, 2010).

\section{Effluent sampling}

In the constructed wetland, the liquid samples were taken below the surface $(<15 \mathrm{~cm})$ at each monitoring point or zone. These samples were stored at $4{ }^{\circ} \mathrm{C}$ and under dark conditions.

\subsection{Analytical methods}

The slurry swine obtained throughout the constructed wetland was characterized for COD (Chemical Oxygen Demand) and $\mathrm{BOD}_{5}$ (Biochemical Oxygen Demand) as described by APHA-AWWA-WPCF (1985). The nutrients TN (Total Nitrogen), $\mathrm{NH}_{4}{ }^{+}-\mathrm{N}$ (Ammonium) and TP (Total Phosphorus) were evaluated by specific kits of NOVA-60 spectroquant. Additionally, potentiometric parameters (temperature, $\mathrm{pH}$, electric conductivity or EC) were measured with a portable Oakton PC650 machine. 
The biomass above and belowground was obtained by dewatering to $75{ }^{\circ} \mathrm{C}$ during 24 hours until reaching constant weight (Keddy et al., 1994).

Proximate analysis in Schoenoplectus californicus (C.A. Méyer) Sójak was performed in the zone below and aboveground. The samples were sealed and analysed by the Agricultural Research Institute (INIA). This analysis considered total carbon (combustion furnace), total nitrogen Kjeldahl (digestion and distillation), phosphorus (calcination and colorimetry) and potassium (calcination and atomic absorption spectrometric) as described by Sadzawka et al. (2004).

\section{Results}

Table 1 shows the physicochemical characteristics of the swine slurry obtained in the fattening phase and fed into the constructed wetland. During the monitoring period, the slurry presents values between 7.2 to 8.7 and high organic matter content $(25.3 \mathrm{~g} \mathrm{COD}$ $\left.\mathrm{L}^{-1}, 14.5 \mathrm{~g} \mathrm{BOD}_{5} \mathrm{~L}^{-1}\right)$, salts $\left(7.4 \mathrm{mS} \mathrm{cm}^{-1}\right)$ and nutrients $\left(2,5 \mathrm{~g} \mathrm{NH}_{4}^{+}-\mathrm{N} \mathrm{L}^{-1}, 1.5 \mathrm{mg} \mathrm{NO}_{3}^{-} \mathrm{L}^{-1}, 194 \mathrm{mg}\right.$ $\left.\mathrm{PO}_{4}^{3--} \mathrm{P} \mathrm{L}^{-1}\right)$, similar to those reported in the literature (Moral et al., 2008).

Table 1. Physicochemical characterization of the swine wastewater

\begin{tabular}{|c|c|c|c|c|}
\hline \multirow[t]{2}{*}{ Parameters } & \multirow[t]{2}{*}{ Units } & \multicolumn{3}{|c|}{ Values } \\
\hline & & Mean $^{b}$ & & $\mathrm{SD}^{\mathrm{a}}$ \\
\hline $\mathrm{pH}$ & & 7.65 & \pm & 0.16 \\
\hline $\mathrm{EC}$ & $\mathrm{mS} \mathrm{cm}{ }^{-1}$ & 7.43 & \pm & 1.63 \\
\hline COD & $\mathrm{g} \mathrm{L}^{-1}$ & 25.25 & \pm & 5.02 \\
\hline $\mathrm{BOD}_{5}$ & $\mathrm{~g} \mathrm{O}_{2} \mathrm{~L}^{-1}$ & 14.52 & \pm & 1.02 \\
\hline $\mathrm{TN}$ & $\mathrm{g} \mathrm{N} \mathrm{L}^{-1}$ & 3.57 & \pm & 0.70 \\
\hline $\mathrm{NH}_{4}+-\mathrm{N}$ & $\mathrm{g} \mathrm{NH}_{4}+-\mathrm{N} \mathrm{L}^{-1}$ & 2.54 & \pm & 1.18 \\
\hline $\mathrm{NO}_{3}-$ & $\mathrm{mg} \mathrm{NO}-\mathrm{L}^{-1}$ & 1.50 & \pm & 0.47 \\
\hline $\mathrm{TP}$ & $\mathrm{mg} \mathrm{PO}_{4}^{3-}-\mathrm{P} \mathrm{L}^{-1}$ & 193.6 & \pm & 9.26 \\
\hline
\end{tabular}

EC: Electric Conductivity; COD: Chemical Oxygen Demand; BOD ${ }_{5}$ : Biochemical Oxygen Demand; TN: Total Nitrogen; TP: Total Phosphorus

${ }^{\mathrm{a}} \mathrm{SD}=$ Standard deviation

${ }^{b}$ Mean values obtained of 12 determinations

Figure 1 shows the allometric growth (height:diameter) of Schoenoplectus californicus (C.A. Méyer) Sójak with respect to the nutrient content present in the swine slurry and in function of the season. When comparing the allometric growth of Schoenoplectus californicus with respect to nutrient content, allometric growth was greater during spring 2010 (86.8) with respect to spring 2009 (39.2). This result may be related with a decreased nitrogen content (3.2 times): $0.16 \mathrm{~kg} \mathrm{~N} \mathrm{ha}^{-1}$ $\mathrm{d}^{-1}$ in 2009 decreased to $0.05 \mathrm{~kg} \mathrm{~N} \mathrm{ha}^{-1} \mathrm{~d}^{-1}$ in 2010 . Seasonally, Schoenoplectus californicus did not show allometric growth in the winter and summer because 
these periods are for pruning (winter) and maturation (summer). The allometric growth in Schoenoplectus californicus recorded for fall 2010 was between 77.5 and 98.5 , where an increase in the phosphorus of 40 mg $\mathrm{P} \mathrm{L}^{-1}$ was also observed due to the plant accretion process. Finally, Schoenoplectuss californicus presented similar allometric growth throughout the wetland.

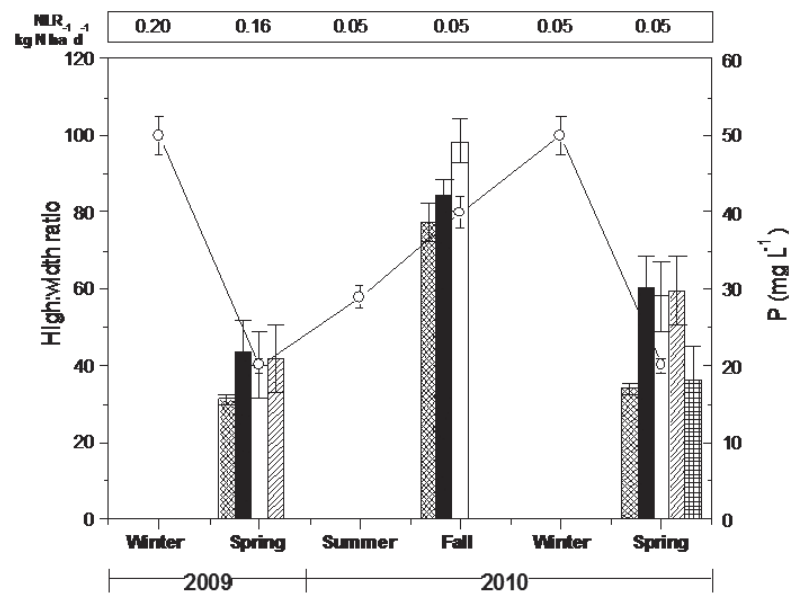

Figure 1. Height:width ratio of Schoenoplectus californicus, phosphorus concentration and nitrogen loading rate

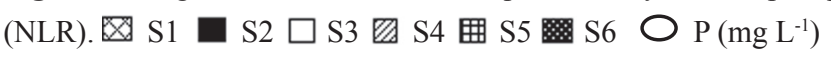

Figure 2 shows the seasonal behaviour for relative abundance (individuals $\mathrm{m}^{-2}$ ) of Schoenoplectus californicus (C.A. Méyer) Sójak with respect to nutrient content in the slurry swine. Schoenoplectus californicus was 5 times more abundant in spring 2010 (108 individuals $\mathrm{m}^{-2}$ ) than in spring 2009 (21 individuals $\mathrm{m}^{-2}$ ). During this period, an increase in the nitrogen content $\left(0.16 \mathrm{~kg} \mathrm{~N} \mathrm{ha}^{-1} \mathrm{~d}^{-1}\right)$ was also registered, possibly due to the abundance of this species in the wetland. The relative abundance decreased in winter and summer (12 individuals $\mathrm{m}^{-2}$ ) in 2010 due to pruning (winter) and the specie's sensitivity to increased temperature (summer). The results obtained are similar to Debing et al. (2010) who reported an abundance of 112 individuals $\mathrm{m}^{-2}$ for Schoenoplectus tabernaemontani for a nitrogen loading between 0.2 to $0.4 \mathrm{~kg} \mathrm{~N} \mathrm{ha}^{-1} \mathrm{~d}^{-1}$. Also, there is a relation between Schoenoplectus californicus and phosphorus in the wetland: the plants are in the senescence period (fall - winter) when phosphorus increases from 40 to $50 \mathrm{mg} \mathrm{P} \mathrm{L}^{-1}$, and the plants are in growth and maturation phase (spring - summer) when it decreases from 20 to $30 \mathrm{mg} \mathrm{P} \mathrm{L}^{-1}$. 


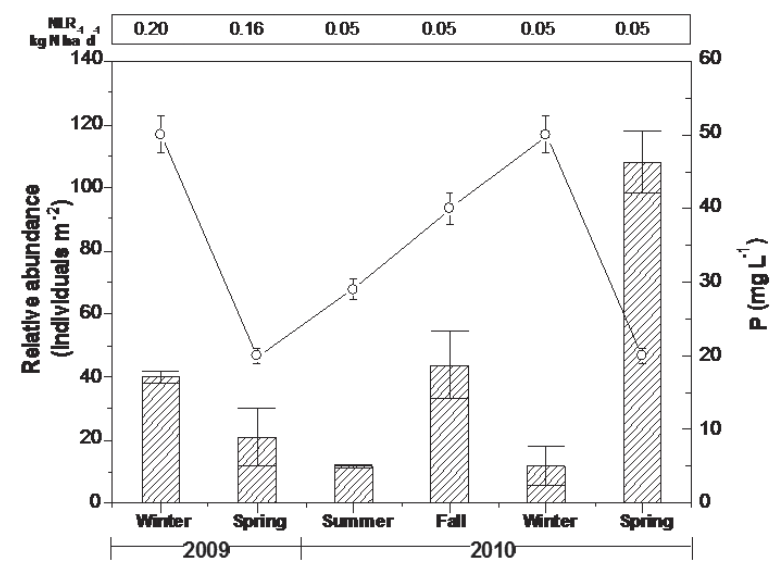

Figure 2. Relative abundance of Schoenoplectus californicus, phosphorus concentration and nitrogen loading rate (NLR). relative abundance (individual $\left.\mathrm{m}^{-2}\right) \bigcirc \mathrm{P}\left(\mathrm{mg} \mathrm{L}^{-1}\right)$

Table 2 summarizes the biomass content and nutrients in Schoenoplectus californicus (C.A. Méyer) Sójak for season. The results show that Schoenoplectus californicus grows about $522 \mathrm{~g} \mathrm{~m}^{-2}$ in the period 2009 and $729 \mathrm{~g} \mathrm{~m}^{-2}$ in 2010. This result may be related with an increase in the nitrogen of 3 to 4 times in 2009. Zhang et al. (2008) worked with Schoenoplectus validus at a load between 0.1 to 1.0 $\mathrm{kg} \mathrm{N} \mathrm{ha}^{-1} \mathrm{~d}^{-1}$ and reported similar growth values (108 $-581 \mathrm{~g} \mathrm{~m}^{-2}$ ). On the other hand, aboveground biomass in Schoenoplectus californicus was between
96 to $99 \%$ greater than biomass belowground, suggesting that the nitrogen can influence further development aboveground. Proximate analysis showed about $42 \%$ corresponded to carbon present in the biomass and only at $3 \%$ to nitrogen, phosphorus and potassium. The N:P relation in the plant was 8.6 and 16 for the period 2009 and 2010, respectively. This result may be related with an increase of 3 to 4 times in the nitrogen, in the period 2009 respect to period 2010. Low values of 0.5 to 8.0 have been reported by Zhang et al. (2008).

Table 2. Proximal analysis of Schoenoplectus californicus (C.A. Méyer) Sójak

\begin{tabular}{|c|c|c|c|c|c|c|c|c|c|c|c|c|}
\hline \multirow{3}{*}{$\begin{array}{l}\text { Compounds } \\
\mathrm{g} \mathrm{m}^{-2}\end{array}$} & \multicolumn{6}{|c|}{ Foliar } & \multicolumn{6}{|c|}{ Rhyzomal } \\
\hline & \multicolumn{3}{|c|}{2009} & \multicolumn{3}{|c|}{2010} & \multicolumn{3}{|c|}{2009} & \multicolumn{3}{|c|}{2010} \\
\hline & Mean $^{\mathrm{b}}$ & & $\mathrm{SD}^{\mathrm{a}}$ & Mean ${ }^{\mathrm{b}}$ & & $\mathrm{SD}^{\mathrm{a}}$ & Mean $^{\mathrm{b}}$ & & $\mathrm{SD}^{\mathrm{a}}$ & Mean $^{\mathrm{b}}$ & & $\mathrm{SD}^{\mathrm{a}}$ \\
\hline Biomass & 500.0 & \pm & 25.0 & 724.2 & \pm & 36.0 & 22.7 & \pm & 1.1 & 4.8 & \pm & 0.2 \\
\hline Carbon & 212.5 & \pm & 10.0 & 304.2 & \pm & 15 & 9.8 & \pm & 0.4 & 2.1 & \pm & 0.1 \\
\hline Nitrogen & 13.1 & \pm & 0.6 & 11.2 & \pm & 0.5 & 0.7 & \pm & 0.0 & 0.1 & \pm & 0.0 \\
\hline Phosphorus & 1.4 & \pm & 0.0 & 0.72 & \pm & 0.0 & 0.1 & \pm & 0.0 & 0.01 & \pm & 0.0 \\
\hline Potasium & 15.1 & \pm & 0.6 & 7.1 & \pm & 0.3 & 0.4 & \pm & 0.0 & 0.03 & \pm & 0.0 \\
\hline
\end{tabular}

${ }^{\mathrm{a}} \mathrm{SD}=$ Standard deviation.

${ }^{\mathrm{b}}$ Mean values obtained of 12 determinations. 
Table 3 summarizes the behaviour of family Cyperaceae species used in constructed wetlands when fed by different types of effluents. Species from the Cyperaceae family with different nitrogen loadings $(0.1$ to $185.0 \mathrm{~kg} \mathrm{~N} \mathrm{ha}^{-1} \mathrm{~d}^{-1}$ ) can present differences with respect to biomass production ( 581 to $3115 \mathrm{~g} \mathrm{~m}^{-2}$ ) and abundance (18 to 344 individuals $\mathrm{m}^{-2}$ ). However, the
$\mathrm{N}: \mathrm{P}$ relation between 0.5 to 8.0 does not show a direct dependence on nitrogen content ( 0.1 to $185 \mathrm{~kg} \mathrm{~N} \mathrm{ha}^{-1}$ $\left.\mathrm{d}^{-1}\right)$ (Kadlec et al., 2005; Jinadasa et al., 2006; Zhang et al., 2008; Debing et al., 2010; Ghosh and Gomal, 2010; Perbangkhem and Polprasert, 2010). The values obtained in this study present behaviour similar to the reports in the literature.

Table 3. Growth behaviour of Cyperaceae species

\begin{tabular}{|c|c|c|c|c|c|c|c|}
\hline Specie & $\begin{array}{c}\text { Wetland } \\
\text { type }\end{array}$ & $\begin{array}{l}\text { Effluent } \\
\text { type }\end{array}$ & $\begin{array}{c}\text { SLR } \\
\operatorname{Kg~N~ha~}^{-1} \mathbf{d}^{-1}\end{array}$ & $\begin{array}{c}\text { Biomass } \\
\mathrm{g} \mathrm{m}^{-2}\end{array}$ & $\begin{array}{l}\mathrm{N}: \mathrm{P} \\
\text { ratio }\end{array}$ & $\begin{array}{c}\text { Abundance } \\
\text { individuals } \\
\mathbf{m}^{-2} \\
\end{array}$ & Reference \\
\hline Sc & FWS & Slurry & $0.05-0.2$ & $522-729$ & $8.6-16.0$ & $12-108$ & This work \\
\hline St & HSSF & Meat/dairy & $32.0-185.0$ & $1316-2023$ & - & - & $\begin{array}{l}\text { Kadlec et al. } \\
(2005)\end{array}$ \\
\hline$S g$ & VSSF & Domestic & 0.1 & $750-2000$ & - & $38-175$ & $\begin{array}{l}\text { Jinadasa et al. } \\
(2006)\end{array}$ \\
\hline$S v$ & VSSF & Domestic & $0.1-1.0$ & $108-581$ & $0.5-8.0$ & $48-64$ & $\begin{array}{l}\text { Zhang et al. } \\
\text { (2008) }\end{array}$ \\
\hline Sv & SSF & $\begin{array}{l}\text { Synthetic } \\
\text { (domestic) }\end{array}$ & $0.2-0.4$ & - & 0.9 & 112 & $\begin{array}{l}\text { Debing et al. } \\
(2010)\end{array}$ \\
\hline$S v$ & HSSF & Milk & $22.0-89.0$ & - & - & $147-344$ & $\begin{array}{l}\text { Ghosh and } \\
\text { Gopal (2010) }\end{array}$ \\
\hline$C p$ & FWS & Domestic & $2.0-12.0$ & $2341-3115$ & - & - & $\begin{array}{l}\text { Perbangkhem } \\
\text { and Polprasert } \\
(2010)\end{array}$ \\
\hline
\end{tabular}

Cp: Cyperus papyrus; Sc: Schoenoplectus californicus; Sg: Scirpus grossus; St: Schoenoplectus tabernaemontani; Sv: Scirpus validus

SLR: Surface Loading Rate; FWS: Free Water Surface; HSSF: Horizontal Subsurface Flow; VSSF: Vertical Subsurface Flow; SSF: Subsurface Flow

\section{Discussion}

Between 60 and $80 \%$ of nitrogen in slurry swine is present as ammonium $\left(2.5 \mathrm{~g} \mathrm{NH}_{4}^{+}-\mathrm{N} \mathrm{L}^{-1}, 1.5 \mathrm{mg} \mathrm{NO}_{3}^{-}\right.$ $\mathrm{L}^{-1}$ ), which is toxic at concentrations greater than 200 $\mathrm{mg} \mathrm{NH}{ }_{4}^{+} \mathrm{L}^{-1}$ (Brix et al, 2002; Clarke and Baldwin, 2002). On the other hand, plants have mechanics, such as protein carriers (glycoprotein, ATM/Rh) of $\mathrm{NH}_{4}^{+} /$ $\mathrm{NH}_{3}$ in its cellular wall (Ludewig et al., 2007), which allow their assimilation and adaptation thus avoiding toxicity (Clarke and Baldwin, 2002). Schoenoplectus californicus is more sensitive and less tolerant to ammonium at concentrations $<100 \mathrm{mg} \mathrm{NH}_{4}^{+} \mathrm{L}^{-1}$ (Miao and Sklar, 1998; Clarke and Baldwin, 2002). Also, in 
this study, Schoenoplectus californicus showed allometric growth inhibition, relative abundance and biomass in period 2009 due to the increase in nitrogen loading from 0.16 to $0.2 \mathrm{~kg} \mathrm{~N} \mathrm{ha}^{-1} \mathrm{~d}^{-1}$.

The phosphorus in this work was found at concentrations of $194 \mathrm{mg} \mathrm{PO}_{4}^{3-}-\mathrm{P} \mathrm{L}^{-1}$ in slurry swine. Phosphorous variation in the wetland can be influenced by the plants since they release phosphorus from their tissues into the liquid phase when the senescence phase begins (Wood et al., 2008). In the constructed wetland in both years, the phosphorus concentrations were between 40 to $50 \mathrm{mg} \mathrm{P} \mathrm{L}^{-1}$ for the fall to winter period and between 20 to $30 \mathrm{mg} \mathrm{P} \mathrm{L}^{-1}$ in spring to summer. It is released with the plant accretion.

Schoenoplectus californicus increases its allometric measurements, such as height, basal diameter (31.2 - 98.4) and relative abundance (21- 108 individuals $\mathrm{m}^{-2}$ ), in early spring and fall, corresponding to the growth and maturation phase. Also, in the 2010 period, the nitrogen decrease to $0.05 \mathrm{~kg} \mathrm{~N} \mathrm{ha}^{-1} \mathrm{~d}^{-1} \mathrm{fa}-$ vours its seasonal growth.

Schoenoplectus californicus in spring period 2009 - 2010 period and fall period 2010 had allometric growth between 31.2 to 41.8 (spring 2009), 34.1 to 60.3 (spring 2010) and between 77.5 to 98.4 (fall 2010) throughout the zones S1, S2, S3 and S4 in the wetland; this is related to the plant's seasonal growth and the nitrogen content of $0.05 \mathrm{~kg} \mathrm{~N} \mathrm{ha}^{-1} \mathrm{~d}^{-1}$ in 2010 .

During the spring and fall 2010, plant growth was limited due to the low temperature (winter) and decrease in the photosynthetic process (Salisbury and Ross, 1994; Richards, 1996; Teal and Howes, 1996). The increased temperature in summer resulted in the death of species in the first months of monitoring because Schoenoplectus californicus is highly sensitive to the increase of temperature and thus requires one year of adaptation (Sistani et al, 1996).
Aboveground biomass production for Schoenoplectus californicus increases between $500-724 \mathrm{~g} \mathrm{~m}^{-2}$ in period 2009-2010, as a result of nutrient capture. On the other hand, the biomass generated below ground decreased from $4.8 \mathrm{~g} \mathrm{~m}^{-2}$ in 2009 to $8-22.7 \mathrm{~g} \mathrm{~m}^{-2}$ in 2010 because Schoenoplectus californicus is a biennial plant.

Nutrient content in the aboveground tissue of Schoenoplectus californicus was between 9 to 16 (N:P relation), while the belowground nutrient content was between 7 to 10 (N:P relation) due to the translocation process of the nutrients from below to above ground, allowing new processes to begin each year (Vymazal et al, 2010). The increase of biomass from 524 to $729 \mathrm{~g} \mathrm{~m}^{-2}$ implies higher nutrient absorption (Miao and Sklar, 1998; Vymazal et al. 2010), which in this case is corroborated by the results delivered by proximate analysis, where the concentrations of nitrogen increased in $13.1 \mathrm{~g} \mathrm{~m}^{-2}$, phosphorus in $1.4 \mathrm{~g} \mathrm{~m}^{-2}$, and potassium in $15.1 \mathrm{~g} \mathrm{~m}^{-2}$ for the above ground section in 2009. This result is related to the nitrogen content between 0.2 to $0.16 \mathrm{~kg} \mathrm{~N} \mathrm{ha}^{-1} \mathrm{~d}^{-1}$ and is higher than in 2010 when it was $0.05 \mathrm{~kg} \mathrm{~N} \mathrm{ha}^{-1} \mathrm{~d}^{-1}$.

\section{Conclusions}

Schoenoplectus californicus (C.A. Meyer), Soják in a constructed wetland fed with slurry swine can reach an allometric growth between 31.2 to 98.4 and relative abundance between 21 to 108 individuals $\mathrm{m}^{-2}$ during the fall and spring seasons. It was influenced by the nitrogen content (between 0.05 to $2.0 \mathrm{~kg} \mathrm{~N} \mathrm{ha}^{-1}$ $\mathrm{d}^{-1}$ ) present in the wetland. The phosphorus content can be affected by the process of plant accretion in the winter and fall periods. Schoenoplectus californicus can grow between 522 a $729 \mathrm{~g} \mathrm{~m}^{-2}$, and is favoured by the nitrogen content about $0.05 \mathrm{~kg} \mathrm{~N} \mathrm{ha}^{-1} \mathrm{~d}^{-1}$ in the period 2010 and inhibited by nitrogen in the period 
2009. The predominance of the plant aboveground with to respect belowground as well as a N:P relation between 8 and 16 suggests the influence of nitrogen present in the wetland on aboveground growth.

\section{Acknowledgements}

This work was supported by CONICYT/PBCT (Grant TPI-01) and Innova Bio Bío (Grant 07-PC S1-198).

The authors thank Mr. C. Contreras from Sucesion Yanine for use of their facilities in the realization of this study.

\section{References}

American Public Health Association (APHA), American Water Works Association (AWWA), Pollution Control Federation (WPCF). 1985. Standard methods for examination of water and wastewater. 17th Edition Washington.

Bezbaruah, A.N., Zhang, T.C. 2004. pH, redox and oxygen microprofile in rhizosphere of bulrush (Scirpus validus) in a constructed wetland treating municipal wastewater. Biotechnol. Bioeng. $88,60-70$.

Brix, H. 1994. Functions of macrophytes in constructed wetlands. Water Sci. Technol. 29, 71-78.

Brix, H. 1997. Do macrophytes play a role in constructed treatment wetlands? Water Sci. Technol. 35, 11-17.

Brix, H., Dyhr-Jensen, K. and Lorenzen, B. 2002. Root-zone acidity and nitrogen source affects $T y$ pha latifolia $\mathrm{L}$. and uptake kinetics of ammonium and nitrate. J. Exp. Bot. 79, 2441-2450.

Clarke, E. and Blaldwin, A. 2002. Response of wetland plants to ammonium and water level. Ecol. Eng. 18, 257-264.
Debing, J., Baoqing, S., Hong, Z. and Juanming, H. 2010. Chemical oxygen demand, nitrogen and phosphorus removal by subsurface wetlands with Phragmites vegetation in different models. Eng. Life Sci. 10, 177-183.

Food and Agriculture Organization of the United States Nations, FAO. 2010. Database of livestock production in 2010 .

Gebremariam, S.Y., Beutel, M.W. 2008. Nitrate removal and DO levels in batch wetland mesocosms: Cattail (Typha spp.) versus bulrush (Scirpus spp.). Ecol. Eng. 34, 1-6.

Ghosh, D. and Gopal, B. 2010. Effect of hydraulic retention time on the treatment of secondary effluent in a subsurface flow constructed wetland. Ecol. Eng. 36, 1044-1051.

Hunt, P., Szogi, A., Humenik, F., Rice, J., Matheny T., and Stone, K. 2001. Constructed wetlands for treatment of swine wastewater from an anaerobic lagoon. Soil \& water division of ASAE. 45, 639647.

Jinadasa, N., Mowjood, M.I.M., Werellagama, D.R.I.B. 2006. Effectiveness of Scirpus grossus in treatment of domestic waste in a constructed wetland. J. Freshw. Ecol. 21, 603-612.

Kadlec, R.H., Tanner, C.C., Hally, V.M., Gibbs, M.M. 2005. Nitrogen spiraling in subsurface-flow constructed wetlands: Implications for treatment response. Ecol. Eng. 25, 365-381.

Kadlec, M. 2008. The effects of wetland vegetation and morphology on nitrogen processing. Ecol. Eng.. 33,126-141.

Keddy P., Twolan-Strutt, L.and Wisheu, I. 1994. Competitive effect and response rankings in 20 wetland plants: are they consistent across three environments?. J. Ecol.. 82, 635-643. 
Lee, C., Fletcher T. and Sun, G. 2009. Nitrogen removal in constructed wetland systems. Eng. Life Sci. 9, 11-22.

Lissner, J., Mendelssohn, I.A., Lorenzen, B., Brix, H., McKee, K.L., Miao, S. 2003. Interactive effects of redox intensity and phosphate availability on growth ad nutrient relations of Cladium jamaicense (Cyperaceae). Am. J. Bot. 90, 736-748.

Ludewig, U., Neuhauser, B., Dynowsji, M. 2007. Molecular mechanisms of ammonium transport and accumulation in plants. FEBS Letters 581, 23012308.

Maddison, M., Mauring, T., Remm, K., Lesta, M., Mander, Ù. 2009. Dynamics of Tyhpa latifolia L., populations in treatment wetlands in Estonia. Ecol. Eng. 35, 258-264.

Miao, S. and Sklar, F. 1998. Biomass and nutrient allocation of sawgrass and cattail along a nutrient gradient. Wetlands Ecol. Manage. 5, 245-263.

Moral, R., Perez-Murcia, M.D., Perez-Espinosa, A., Moreno-Caselles, J., Paredes, C. 2005. Estimation of nutrient values of pig slurries in Southeast Spain using easily determined properties. Waste Manage. 25, 719-725.

Perbangkhem, T., Polprasert, C. 2010. Biomass production of papyrus (Cyperus papyrus) in constructed wetland treating low-strength domestic wastewater. Bioresour. Technol. 101, 833-835.

Poach, M., Hunt, P., Reddy, G., Stone, K., Johnson, M. and Grubbs, A. 2003. Swine wastewater treatment by marsh-pond-marsh constructed wetlands under varying nitrogen loads. Ecol. Eng. 23, 165175.

Reddy K.R., D`Angelo, E.M., DeBusk, T.A. 1989. Oxygen transport through aquatic macrophytes:the role in wastewater treatment. J. Environ. Qual. $19,261-267$.

Reddy, K.R. and D'Angelo, E.M. 1997. Biogeochemical indicators to evaluate pollutant removal effi- ciency in constructed wetlands. Water Sci. Technol. 5, 1-10.

Richards, F. 1996. Plant Phisiology. The quantitative analysis of growth. Analysis of Growth: Behavior of Plants and Their Organs. Academic Press. New York Eitorial.101 pp.

Sadzawka A., Carrasco M., Grez R. y Mora M. 2004. Métodos de análisis de tejidos vegetales. Comisión de normalización y acreditación. Sociedad chilena de la ciencia del suelo.

Sistani, K., Mays, D. and Taylor, R. 1996. Development of natural conditions in constructed wetlands: biological and chemical changes. Ecol. Eng. 12, 125-131.

Stein, O.R., Hook, P.B. 2005. Temperature, plants and oxygen: How does season affect constructed wetland perfomance? J. Environ. Sci. Health. 40, 1331-1342.

Teal, J. and Howes, B. 1996. Interannual variability of a salt-marsh ecosystem. Limnology and Oceanography 41: 802-809.

Vymazal, J., Kropfelova, L., Jaroslav, J. and Stichovac, J. 2010. Can multiple harvest of aboveground biomass enhance removal of trace elements in constructed wetlands receiving municipal sewage?. Ecol. Eng. 36, 939-945.

Wood, J., Gordon, R., Madani, A., and Stratton, G. 2008. A long term assessment of phosphorus treatment by a constructed wetland receiving dairy wastewater. Wetlands. 28, 715-723.

Zhang, Z., Rengel, Z., Meney, K. 2008. Interactive effects of nitrogen and phosphorus loadings on nutrient removal from simulated wastewater using Schoenoplectus validus in wetland microcosms Chemosphere. 72, 1823-1828.

Zhang, Z., Rengel, Z., Meney, K. 2009. Kinetics of ammonium, nitrate and phosphorus uptake by Canna indica and Schoenoplectus validus. Aquat. Bot. 91, 71-74. 